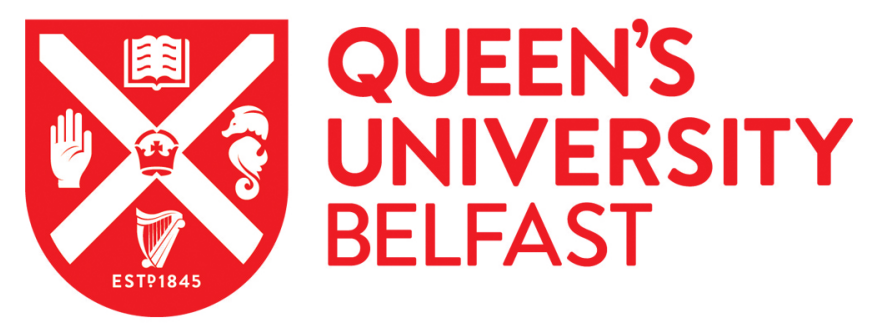

\title{
In vitro profiling of the potential endocrine disrupting activities affecting steroid and aryl hydrocarbon receptors of compounds and mixtures prevalent in human drinking water resources
}

Connolly, L. (2020). In vitro profiling of the potential endocrine disrupting activities affecting steroid and aryl hydrocarbon receptors of compounds and mixtures prevalent in human drinking water resources. Chemosphere, 258. https://doi.org/10.1016/j.chemosphere.2020.127332

Published in:

Chemosphere

Document Version:

Peer reviewed version

Queen's University Belfast - Research Portal:

Link to publication record in Queen's University Belfast Research Portal

\section{Publisher rights}

Copyright 2020 Elsevier.

This manuscript is distributed under a Creative Commons Attribution-NonCommercial-NoDerivs License

(https://creativecommons.org/licenses/by-nc-nd/4.0/), which permits distribution and reproduction for non-commercial purposes, provided the author and source are cited.

\section{General rights}

Copyright for the publications made accessible via the Queen's University Belfast Research Portal is retained by the author(s) and / or other copyright owners and it is a condition of accessing these publications that users recognise and abide by the legal requirements associated with these rights.

Take down policy

The Research Portal is Queen's institutional repository that provides access to Queen's research output. Every effort has been made to ensure that content in the Research Portal does not infringe any person's rights, or applicable UK laws. If you discover content in the

Research Portal that you believe breaches copyright or violates any law, please contact openaccess@qub.ac.uk. 


\section{In vitro profiling of the potential endocrine disrupting activities affecting steroid and aryl hydrocarbon receptors of compounds and mixtures prevalent in human drinking water resources}

Doan $\mathrm{TQ}^{1}$, Connolly $\mathrm{L}^{2}$, Igout $\mathrm{A}^{3}$, Nott $\mathrm{K}^{4}$, Muller $\mathrm{M}^{5^{*}}$, Scippo $\mathrm{ML}^{1^{*}}$

${ }^{1}$ Laboratory of Food Analysis, FARAH-Veterinary Public Health, University of Liège, Liège, Belgium, 4000;

${ }^{2}$ Institute for Global Food Security, School of Biological Sciences, Queen's University Belfast, Northern Ireland, UK, BT9 5DL;

${ }^{3}$ Department of biomedical and preclinical sciences, Faculty of Medicine, University of Liège, Liège, Belgium, 4000;

${ }^{4}$ La société wallonne des eaux (SWDE), Verviers, Belgium, 4800;

${ }^{5}$ GIGA-R, Laboratory for Organogenesis and Regeneration, University of Liège, Liège, Belgium, 4000;

Corresponding author Scippo ML: mlscippo@uliege.be

*Muller M and Scippo ML equally contributed as the last authors.

\section{Abstract}

Prioritizing chemicals posing threats to drinking water resources is crucial for legislation considering the cost of water treatment, remediation, and monitoring. We profiled in vitro potential endocrine disrupting activities (both agonistic and antagonistic) of 18 contaminants most prevalent in Walloon raw water resources intended for drinking water production, including several compound groups: pesticides, perfluorinated compounds, polycyclic aromatic hydrocarbons, a corrosion inhibitor, and bisphenol A. Mixtures thereof relevant for human realistic exposure were also investigated. Seven luciferase reporter gene cell lines were used i.e. three (human and rat) responsive to dioxins through the aryl hydrocarbon 
receptor $(A h R)$ and four (human) responsive to steroids through the estrogen (ER), androgen $(A R)$, progesterone (PR), and glucocorticoid (GR) receptors. Among the 18 compounds, ten caused at least one response in at least one receptor. Specifically, chlorpyrifos, bisphenol A, fluoranthene, phenanthrene, and benzo[a]pyrene displayed significant activities on several receptors. Bisphenol A agonized ER, but abolished the cells' response to androgen and progesterone. While fluoranthene and phenanthrene strongly reduced human $A h R$ and $A R$ transactivation, benzo[a]pyrene strongly activated $A h R$ and $E R$, but inhibited GR and AR. In human breast cancer cells, benzo[a]pyrene dramatically activated AhR, inducing a 10-fold higher response than 2,3,7,8-tetrachlorodibenzodioxin (TCDD) at concentrations possibly found realistically in human blood. The mixture of the 18 compounds exerted both ER and rat AhR agonism, with the main contribution being from benzo[a]pyrene or its combination with bisphenol A. Moreover, the mixture significantly inhibited TCDD-induced CYP1A activity (detected only by EROD assays) in human hepatoma cells.

Keywords: Raw water; Reporter gene assays; Endocrine disrupting activities; Aryl hydrocarbon receptor; Steroid receptors; Benzo[a]pyrene.

\section{Highlights:}

- Endocrine disrupting in vitro profile of 18 pollutants in drinking water resources.

- Chlorpyrifos, BPA, fluoranthene, phenanthrene, B[a]P display significant activities.

- $\mathrm{B}[\mathrm{a}] \mathrm{P}$ strongly induces AhR in human breast cancer cells to 10-fold higher than TCDD.

- The mixture exerts $\mathrm{ER}$ and rat $\mathrm{AhR}$ agonisms due to $\mathrm{B}[\mathrm{a}] \mathrm{P}$ or its combination with BPA.

- EROD assays can detect effects of the mixture on TCDD-induced CYP1A activity in human hepatoma. 


\section{1. Introduction}

2 Since drinking water is an unavoidable route exposing humans to pollutants, access to safe 3 drinking water is crucial for public health ${ }^{1}$. Several legislations impose maximal limits of 4 contaminants for the quality of water intended for human consumption, e.g. the Safe Drinking 5 Water Act (SDWA) in the US², the Drinking Water Guidelines (ADWG) in Australia ${ }^{3}$, and the 6 Drinking Water Directive 98/83/EC in the $\mathrm{EU}^{4}$. Endocrine disruptors (EDs), a group of exogenous substances that can interfere with the endocrine system thereby affecting the health of animals and humans, are of particular concern. Exposure to EDs even at low doses is associated with several health problems including abnormal reproductive activity, high incidence of cancers, and metabolic disorders e.g. obesity and cardiovascular diseases ${ }^{5-7}$.

12 EDs can alter the endocrine system in various ways, one of them is by affecting the activities 13 of the crucial transcriptional factors e.g. the steroid (estrogen (ER), androgen (AR), 14 glucocorticoid (GR), and progesterone (PR)) receptors and the aryl hydrocarbon receptor $15(\mathrm{AhR})$ which controls xenobiotic metabolism ${ }^{7,8}$. The steroid receptors are regulated by steroids e.g. 17ß-estradiol (E2), 5- $\alpha$-dihydrotestosterone (DHT), dexamethasone (Dex), progesterone (P4), respectively, while 2,3,7,8-tetrachlorodibenzo-p-dioxin (TCDD) is the typical ligand of the AhR. The ligand-bound receptors bind to their cognate DNA sequences (i.e. steroid or dioxin responsive elements, respectively) located in the promotor regions of their target genes to activate gene transcription ${ }^{9,10}$.

Luciferase reporter gene assays take advantage of this series of events to establish reporter cell lines that are able to respond to the presence of ligands/stimuli ${ }^{11}$. They thus accurately reproduce the mechanism of action of these compounds at the cellular level, as in a living organism $^{12}$. They are also able to discriminate between agonistic and antagonistic activities (by co-exposing the cells to the test compound and a typical agonist) ${ }^{11}$. Moreover, they have been internationally validated to provide mechanistic and semi-quantitative data ${ }^{13,14}$ and have 
shown a good correlation with in vivo experiments for several EDs ${ }^{15,16}$. They are also able to reveal unknown properties especially of complex mixtures ${ }^{11}$.

While there is still a need for research on protecting human health against the effects of EDs in drinking water ${ }^{7}$, especially in mixture forms which are more relevant for human exposure, prioritizing chemicals posing the threats is crucial considering the cost of water treatment, remediation, and monitoring. The Walloon Government in Belgium has recently funded the BIODIEN project ("search for EDs in waters") aiming to quantify the contamination by specific EDs of several Walloon and Brussels water bodies. Among the 194 compounds monitored, 58 have been quantified at least once in 100 samples of raw water (surface and ground) intended for drinking water production ${ }^{17}$. However, the potential health effects of these chemicals as individuals and as mixtures have not yet been investigated, making difficult to prioritize the regulation of certain compounds/groups.

In this study, the endocrine disrupting activities of 18 compounds most frequently found in Wallonia raw water intended for drinking water production and their mixtures were investigated using luciferase reporter gene assays for five receptors (AhR, ER, AR, GR, and PR). The aims were to (a) assess both transcriptional agonistic and antagonistic activities of these compounds individually and in mixtures towards the five receptors, (b) identify the most concerning endocrine disrupting compound(s), and (c) identify the main compound(s) responsible for the observed effects of the mixtures.

\section{Materials and methods}

\subsection{Chemicals and suppliers}

We selected 19 compounds based on their highest frequency of quantification (> 8\%) in the raw water samples from the BIODIEN project. VIS01 was excluded since no analytical standard available on the market. The main results of their monitoring during the BIODIEN 
project and their suppliers are given in Table 1. The 18 selected compounds belong to several groups: eight pesticides and pesticide metabolites, five perfluorinated compounds (PFCs), three polycyclic aromatic hydrocarbons (PAHs), a corrosion inhibitor (1H-benzotriazole), and a plasticizer (bisphenol A, BPA). Reference standards, E2, DHT, Dex, and P4 were supplied by Sigma Aldrich (Missouri, USA), while TCDD was provided by Wellington (Campro Scientific, The Netherlands). All chemicals were dissolved in dimethylsulfoxide (DMSO, Acros Organics, France) and stored at $-20^{\circ} \mathrm{C}$. Tested concentration ranged from $1.25 \mu \mathrm{M}$ to $40 \mu \mathrm{M}$ in a series of six 2-fold dilutions, which has been shown to be suitable for the reporter gene assays without cytotoxicity ${ }^{18,19}$.

64

\subsection{Mixture preparation}

A mixture of the 18 chemicals called the ED mixture, was constructed according to the maximum detected concentrations $\left(\mathrm{C}_{\max }\right)$ in the raw water samples by pooling each component from their respective stock solutions. The concentrations of pesticides and PAHs in the mixture were measured by liquid chromatography- tandem mass spectrometry (LCMS/MS) and gas chromatography-tandem mass spectrometry (GC-MS/MS) using in-house methods available in Société Wallonne des Eaux (SWDE) (see "measured concentration- $\mathrm{C}_{\mathrm{m}}$ " in Table 1). PAHs were present in the mixture at lower concentration than expected, which could be due to their absorption by the glass container. To study the possible interactions among compound groups, a PFC mixture (five PFCs), a PEST mixture (eight pesticides, $1 \mathrm{H}$ benzotriazole and BPA), and a PAH mixture (three PAHs) were also prepared. The tested concentrations of the mixtures are given as "fold maximal water levels" relative to their concentrations present in water samples (Table 1). The maximum final tested concentration $\left(C_{t}\right)$ was 1000 fold, except desphenyl-chloridazon (DPC) which was 100 fold due to its very high concentration in water (it was not possible to make up 1000 fold, which corresponds to $14810^{-6} \mathrm{M}$, due to stock unavailability). 
83 Seven genetically modified cell lines expressing the reporter gene luciferase were used. Three dioxin responsive cell lines: rat hepatoma DR-H4IIE from BioDetection System (Amsterdam, The Netherlands), human hepatoma HepG2-Luc and human mammary gland T47-D-Luc (both produced on site in Liege, Belgium) ${ }^{20}$, were used to compare the AhR transcriptional activity between species (rat and human) and tissues (liver and mammary gland). DR-H4IIE cells were stably transformed with a vector containing four native dioxin responsive elements (DREs) from the upstream promotor of the mouse Cyp1a1 gene with a MMTV (mouse mammary tumor virus) promoter ${ }^{21}$, while four synthetic DREs regulating the thymidine kinase promoter were in both T47-D-Luc and HepG2-Luc cells ${ }^{20}$. The four human steroid responsive cell lines (ER-MMV-Luc, TARM-Luc, PR-TM-Luc and TGRM-Luc) addressing respectively the estrogen, androgen, progesterone and glucocorticoid receptor, were previously described ${ }^{11}$. ER-MMV-Luc cells were MCF-7 cells transformed with a vector containing the luciferase gene controlled by a vitellogenin promoter. The other three steroid reporter cells were derived from T47-D cells sharing a common vector containing the MMTV-LTR (long terminal repeat) promoter, inducible by glucocorticoid, progesterone, and androgen ligands ${ }^{11}$. While ER-MMVLuc and PR-TM-Luc responded through their endogenous receptors, TGRM-Luc and TARMLuc were stably transformed with an additional expression vector coding for, respectively human GR and AR.

101

102 The cells were maintained in MEM $\alpha$ (ThermoFisher Scientific, Massachusetts, USA), except

103 for ER-MMV-Luc in DMEM (ThermoFisher Scientific) supplemented with $1 \mu \mathrm{gm} / \mathrm{L}$ bovine 104 pancreas insulin (Sigma Aldrich). Both media were supplemented with $10 \% \mathrm{v} / \mathrm{v}$ fetal bovine 105 serum (FBS) (Greiner, Kremsmünster, Austria), $50 \mathrm{IU} / \mathrm{mL}$ penicillin and $50 \mu \mathrm{g} / \mathrm{mL}$ streptomycin 106 (Sigma Aldrich). The cells were incubated in a $\mathrm{H}_{2} \mathrm{O}$ saturated atmosphere containing $5 \% \mathrm{CO}_{2}$, 107 at $37^{\circ} \mathrm{C}$. In the rest of the manuscript, MEM $\alpha$ and DMEM will stand for the respective medium 108 supplemented with FBS and penicillin and streptomycin. 


\subsection{Reporter gene assays}

110 Different protocols for each cell line were described in detail elsewhere ${ }^{11,20}$. Briefly, after $24 \mathrm{~h}$

111 of cell seeding in white clear-bottomed 96 well microplates (Greiner) with 90\% cell confluence,

112 the medium was refreshed and the cells were exposed to a dilution series of the tested

113 compound/mixture mentioned above. A reference curve of the reference ligand along with the

114 blank DMSO was performed on each plate for quality control. For co-exposure tests, the same

115 dilution series was used on cells that were cotreated with a constant concentration of the

116 reference compound, close to its $\mathrm{EC}_{50}$ (Table S1). The AhR reporter cells were exposed for

$11724 \mathrm{~h}$ in MEM $\alpha$, while the steroid reporter cells were exposed for 48h in DMEM without phenol

118 red and supplemented with charcoal stripped FBS to eliminate natural steroid activators. After

119 exposure, the cells were lysed by solutions containing Triton X100 (Sigma Aldrich). The

120 luminescence signal was recorded by adding luciferin (Promega, Wisconsin, USA) and ATP

121 (Roche Diagnostics, Rotkreuz, Switzerland) to the cell lysate and measured by a luminometer

122 (ORION II, Berthold Detection System, Pforzheim, Germany). The final concentration of

123 DMSO was $0.2 \%$ and $0.3 \%$ for the agonistic and co-exposure tests, respectively. All tests

124 were performed in at least three independent experiments, each in triplicate. The cytotoxicity

125 was examined by visually inspecting the cell morphology and density under the microscope

126 before cell lysis.

128 Table S1 shows the characteristics of the seven reporter gene cell lines. In general, the cell

129 lines performed similarly as in the previous studies i.e. similar $\mathrm{EC}_{50}$ and fold induction ${ }^{11,19,22}$,

130 except a reduction of the maximal fold induction seen for TGRM-Luc (from around 2000 fold

131 to 320 fold) and an increase of $\mathrm{EC}_{50}$ for PR-TM-Luc $\left(705 \pm 40 \times 10^{-9} \mathrm{M}\right.$ compared to $1.5 \times 10^{-}$

$132{ }^{9} \mathrm{M}$ ), however the latter value was close to that observed of $330 \pm 0.9 \times 10^{-9} \mathrm{M}$ in a recent 133 study ${ }^{23}$. 


\subsection{EROD assays in HepG2-Luc and T47-D-Luc}

136 EROD assays measure the activity of ethoxyresorufin-O-deethylase (eroD) enzyme that is 137 associated with CYP1A converting ethoxyresorufin to fluorescent resorufin. They were thus 138 used to determine the CYP1A activity of the mixtures in HepG2-Luc and T47-D-Luc. The 139 EROD assays were performed according to Schiwy et al., (2015) ${ }^{24}$ with the exposure 140 conditions as described for the reporter gene assays. However, to adjust to the much higher

141 TCDD sensitivity of EROD assays towards the AhR from both human cell lines, the maximum 142 TCDD concentrations were 20 and 40-fold lower (500 pM for HepG2-Luc and 250 pM for T47-

$143 \mathrm{D}$-Luc) than in the reporter gene assays (10 $\mathrm{nM}$ for both), and the corresponding TCDD 144 concentration used in the co-exposure tests was respectively $100 \mathrm{pM}$ and $50 \mathrm{pM}$, instead of $145650 \mathrm{pM}$ and $150 \mathrm{pM}$. After $24 \mathrm{~h}$ exposure, $100 \mu \mathrm{l}$ of working solution, freshly prepared by 146 dissolving 7-ethoxyresorufin (5 $\mu \mathrm{M})$ (Sigma Aldrich) in DMEM without phenol red, was added 147 into $50 \mu \mathrm{l}$ lysed-cell extract, followed by an incubation for 30 minutes at $37^{\circ} \mathrm{C}$ in the dark. To 148 terminate the reaction, $100 \mu \mathrm{l}$ chilled to $4^{\circ} \mathrm{C}$ methanol (Merck, Massachusetts, USA) was 149 added. The fluorescence signal of resorufin was measured at 550/595 nm using a Perkin 150 Elmer VICTOR X5 MultiLabel Plate Reader, Germany.

\subsection{Calculations of relative responses $R R, E_{50}, I C_{50}$, and efficacy}

153 The cells' responses were obtained as relative light units (RLUs). The activities of the compound/mixture $(n)$ for both reporter gene and EROD assays were presented as relative responses $\left(R R_{a(n)}\right.$ and $R R_{i(n)}(\%)$ for agonistic and co-exposure tests, respectively) and determined as:

(1) $R R_{a(n)}=\frac{R_{a(n)}-R_{D M S O}}{R_{(\text {ref-max })}-R_{D M S O}} \times 100$

(2) $R R_{i(n)}=\frac{R_{i(n)}-R_{D M S O}}{R_{(r e f-E C 50)}-R_{D M S O}} \times 100$

$159 R_{a(n)}$ (Eq. 1) or $R R_{i(n)}$ (Eq. 2) was the percentage (\%) of the agonistic $\left(R_{a(n)}\right)$ or co-exposure $160\left(R_{i(n)}\right)$ response of the compound/mixture $(n)$ compared to the maximum response $\left(R_{(r e f-m a x)}\right)$ or 
161 to the response of the spike-in $E_{50}\left(R_{(\text {ref-EC50) }}\right)$ of the reference compound, both after

162 subtraction of the vehicle (DMSO) response $\left(R_{D M S O}\right)$. A value of $R R_{i(n)}(\%)$ higher than $100 \%$

163 reflected an additive/enhancing action of the compound/mixture on top of the effect caused

164 by the presence of the reference compound at $\mathrm{EC}_{50}$ (marked as "+" in Table 3). Meanwhile, a

165 value less than $100 \%$ demonstrated the antagonistic potential of the compound/mixture to 166 inhibit the activity of the reference compound at $E C_{50}$, thus, the lower the $R_{\mathrm{i}(\mathrm{n})}(\%)$ was, the 167 stronger the antagonistic activity.

168

169 The dose-response curves were generated by fitting a four-parameter non-linear stimulation

170 or inhibition regression (Graphpad PRISM software, version 7, San Diego, California, USA)

171 for agonistic (Eq. 3) or antagonistic (Eq. 4) tests:

(3) $R R_{a(n) x}=B+\frac{x^{H}(T-B)}{x^{H}+E C_{50}{ }^{H}}$

184

(4) $R R_{i(n) x}=B+\frac{T-B}{1+\frac{x^{H}}{I C_{50}{ }^{H}}}$

173 where $x$ was the concentration of the tested compound/mixture inducing the relative response

$174 \mathrm{RR}_{\mathrm{a}(\mathrm{n}) \times}$ or $\mathrm{RR}_{\mathrm{i}(\mathrm{n}) \mathrm{x}} . \mathrm{EC}_{50}$ and $\mathrm{IC}_{50}$ were the half maximal effective concentrations for an agonist 175 and antagonist, respectively ${ }^{25}$, note that no $\mathrm{IC}_{50}$ was determined for the additive activities. $\mathrm{B}=$ 176 bottom, $\mathrm{T}=\mathrm{Top}, \mathrm{H}=$ Hillslope. $\mathrm{B}$ was constrained higher than $\mathrm{0}$, respectively for the minimum 177 and maximum responses in agonistic and antagonistic tests. A compound/mixture was 178 considered active if its effect was significantly different from that of DMSO alone (ANOVA, 179 Graphpad PRISM, $p<0.05)$. The efficacy $\left(\mathrm{RR}_{a / \max }\right.$ or $\mathrm{RR}_{\mathrm{i} / \max }(\%)$ for agonistic or antagonistic 180 activities, respectively) was determined as the significant maximum effect of the 181 compound/mixture (ANOVA, Graphpad PRISM, $p<0.05$ ). When no full dose response curve 182 was obtained, $\mathrm{RR}_{\mathrm{a} / \mathrm{max}}$ or $\mathrm{RR}_{\mathrm{i} / \mathrm{max}}$ was assigned as the effect induced by the highest tested 183 concentration of the compound/mixture. 


\section{Results}

\section{3.1. Activities of the 18 compounds}

187 No cytotoxicity was recorded for any of the 18 compounds within the concentration range

188 tested for both agonistic and co-exposure experiments. Among eight pesticides, methyl189 desphenyl-chloridazon (Me-DPC) and desethylatrazine exerted weak agonistic responses 190 that were best observed when cells were cotreated with TCDD, respectively in DR-H4IIE and 191 T47-D-Luc (Figures 1B and 1F'), while atrazine antagonized TCDD activity in HepG2-Luc with $192 R R_{i / \max }=70 \%$ (Figure 1D). The most active pesticide was chlorpyrifos, inducing in DR-H4IIE 193 and ER-MMV-Luc both weak agonistic $\left(\mathrm{RR}_{\mathrm{a} / \max }=\sim 10 \%\right)$ (Figures $1 \mathrm{~A}$ and $\left.1 \mathrm{G}\right)$ and significant 194 antagonistic responses (Figure $1 \mathrm{~B}$ and $1 \mathrm{H})\left(\mathrm{RR}_{\mathrm{i} / \max }=62 \%\right.$ and $43 \%$, respectively), while it 195 was only agonistic $\left(R_{a / \max }=27 \%\right)$ in T47-D-Luc (Figure 1E') and only antagonistic $\left(R R_{i / \max }=\right.$ 196 68\%) in PR-TM-Luc (Figure 1J).

BPA strongly induced the response of ER-MMV-Luc with $R_{R_{a / \max }}=119 \%$, higher than the maximum response of E2 (Figure 1G), but did not cause any effect when cells were coexposed with E2. It also inhibited the responses of the four T47D-derived transgenic lines in the co-exposure tests, moderately in T47-D-Luc and TGRM-Luc (Figures 1F' and 1I), and particularly strongly in PR-TM-Luc and TARM-Luc with $\mathrm{RR}_{\mathrm{i} / \max }=15 \%$ (Figures $1 \mathrm{~J}$ and $1 \mathrm{~K}$ ).

204 The most potent group was PAHs, which caused a response in all seven cell lines, except phenanthrene which displayed no response in ER-MMV-Luc, TGRM-Luc, and PR-TM-Luc. Interestingly, fluoranthene and phenanthrene behaved differently from benzo[a]pyrene

$207(B[a] P)$. While phenanthrene did not induce agonistic activities in any cell line, fluoranthene 208 caused a weak agonistic response, with $\mathrm{RR}_{\mathrm{a} / \max }=21 \%$ and $28 \%$ in DR-H4IIE and ER-MMV209 Luc, respectively (Table 2). However, they both strongly inhibited the TCDD response with $210 R R_{i / \max }=\sim 40 \%$ in DR-H4IIE, and even more strongly in HepG2-Luc and T47-D-Luc $\left(R R_{i / \max }=\right.$ $211 \sim 10 \%)$. Fluoranthene also antagonized P4 in PR-TM-Luc and DHT in TARM-Luc with RR $\mathrm{R}_{\mathrm{i} / \max }$ 
$212=62 \%$ and $16 \%$, respectively, whereas phenanthrene inhibited only the TARM-Luc response

213 with $\mathrm{RR}_{\mathrm{i} / \max }=34 \%$ (Table 3).

$215 \mathrm{~B}[\mathrm{a}] \mathrm{P}$ was a potent agonist in DR-H4IIE with $\mathrm{RR}_{\mathrm{a} / \max }=171 \%$, nearly twice the cells' maximum response to TCDD (Figure $1 \mathrm{~A})$. The effect remained when it was co-exposed with $\mathrm{EC}_{50}$ TCDD with $R R_{i / \max }=280 \%$ (Figure $\left.1 \mathrm{~B}\right)$, since this resulted in a final $\mathrm{RR}_{\mathrm{a}(\mathrm{C} 19) / \max }=126 \%$ after the spike-in $\mathrm{EC}_{50}$ reference was subtracted and the response $\mathrm{RR}_{\mathrm{a}(\mathrm{C} 19)}$ was compared to the maximum response of the reference compound. $\mathrm{B}[\mathrm{a}] \mathrm{P}$ was also able to agonize human $\mathrm{AhR}$ in hepatoma HepG2-Luc, but to a lesser extend $\left(R R_{a / \max }=27 \%\right)$ (Figure $\left.1 \mathrm{C}\right)$, causing a partially antagonistic activity in this cell line when co-exposing with TCDD, showing an antagonistic activity up to $10 \mu \mathrm{M}$ and an agonistic activity at higher concentrations (Figure 1D). Surprisingly, B[a]P induced an extremely strong agonistic response in human mammary gland carcinoma T47-D-Luc, with $\mathrm{RR}_{\mathrm{a} / \max }=1061 \%$ (Figure 1E), which remained similar in the coexposure test with $R R_{i / \max }=2713 \%$ or a final $R R_{a(C 19) / m a x}=1266 \%$ (Figure $\left.1 F\right)$, indicating that the presence of TCDD did not affect the B[a]P activity in this cell line.

In ER-MMV-Luc, B[a]P induced a strong agonistic response of $R_{a / \max }=253 \%$, while in the presence of E2, an inhibition was observed at lower concentrations and an activation at higher concentration, parallel to the agonistic curve with $R R_{i / \max }=233 \%$ or $R R_{a(C 19) / \max }=102 \%$, less than half of $R^{a / \max }$ (Figures $1 \mathrm{G}$ and $1 \mathrm{H}$ ). It also caused a similar response in PR-TM-Luc, but only when co-exposing the cells with $\mathrm{P} 4$, with $\mathrm{RR}_{\mathrm{i} / \mathrm{max}}=172 \%$ or $\mathrm{RR}_{\mathrm{a}(\mathrm{C} 19) / \max }=111 \%$ (Figure 1J). Moreover, B[a]P significantly antagonized both Dex and DHT in TGRM-Luc and TARM-

234 Luc with $\mathrm{RR}_{\mathrm{i} / \max }=36 \%$ and $9 \%$, respectively. All these data are summarized in Tables 2 and 3 and Figure $1 S$.

\subsection{Activities of the mixtures}

238 No activity was observed for the PFC mixture. In DR-H4IIE, the ED mixture showed an agonistic activity similar to that of the PAH mixture with $\mathrm{RR}_{\mathrm{a} / \mathrm{max}}=42 \%$ and $45 \%$, respectively, 
240 while the PEST mixture activation was lower $\left(R R_{a / \max }=17 \%\right)$. In comparison, the ER-MMV-

241 Luc responded similarly to both the PAH and PEST mixtures with $\mathrm{RR}_{a / \max }=17 \%$ and $16 \%$, 242 respectively, while the ED mixture caused a strong agonistic effect $\left(R R_{a / \max }=32 \%\right)($ Table 2$)$.

244 Additive responses of these mixtures were observed when the cells were co-exposed with 245 TCDD or E2 (Table 3). However, the additive responses were not significant in DR-H4IIE with only $\mathrm{RR}_{\mathrm{i} / \mathrm{max}}=\sim 125 \%$ for both ED and PAH mixtures, and only $115 \%$ for the PEST mixture. $\mathrm{A}$ similar result was obtained in ER-MMV-Luc $\left(\mathrm{RR}_{\mathrm{i} / \max } \mathrm{PAH}\right.$ and ED $=145 \%$ and PEST $\left.=122 \%\right)$. Since full dose response curves were not obtained within the tested concentration range, no values could be deduced for $\mathrm{EC}_{50}$ and for the additive $\mathrm{IC}_{50}$ (Tables 2 and 3 ).

From Table 2, it seems that the observed agonistic effects of the PAH and ED mixtures in DRH4IIE were due to the agonistic activity of $B[a] P$, while the agonistic effect seen for the $E D$ mixture in ER-MMV-Luc was due to the combination of $\mathrm{B}[\mathrm{a}] \mathrm{P}$ and BPA. This assumption was confirmed by testing the concentrations of $\mathrm{B}[\mathrm{a}] \mathrm{P}, \mathrm{BPA}$, and $\mathrm{B}[\mathrm{a}] \mathrm{P}+\mathrm{BPA}$ corresponding to their concentrations in the mixtures (Figure 2A). No major contributor could be identified for the weak agonism of the PEST mixture in DR-H4IIE.

\subsection{EROD assays with the mixtures in HepG2-Luc and T47-D-Luc}

259 The CYP1A inducing activity of the mixtures on the two human AhR reporter cell lines was 260 determined using the EROD assays. In T47-D-Luc, while only an agonistic effect was observed for the ED mixture in the reporter gene assays, there was a moderate agonistic response seen for the PAH mixture with $R_{a / \max }=45 \%$ (Figure 2B1) and weak antagonistic responses seen for the PEST and ED mixtures (RR $\mathrm{R}_{\mathrm{i} \max }<80 \%$ ) (data not shown). The PEST and ED mixtures induced the same antagonistic responses in HepG2-Luc with $\mathrm{IC}_{50}$ PEST $=$ $180 \pm 25$ and $I C_{50} E D=177 \pm 23$ fold and $R_{i / m a x} P E S T=16 \%$ and $R R_{i / \max } E D=14 \%$, while the PAH mixture displayed a weaker response of $\mathrm{RR}_{\mathrm{i} / \max }=67 \%$ (Figure 2B2). 


\section{Discussion}

\section{4.1. Endocrine disrupting activities of the 18 compounds}

269 This study is one of the few studies ${ }^{22,23,26-30}$ using a panel of multiple cell-based bioassays 270 (seven reporter gene cell lines including five receptors (AhR, ER, GR, PR, and AR)) for in vitro 271 profiling of the potential endocrine disrupting activity of multiple chemicals which were

272 frequently detected in Wallonia raw water intended for drinking water production. Appearing 273 with relatively high frequency of quantification (FOQ), several herbicides (DPC, metolachlor 274 ESA, BH479-8, simazine), $1 \mathrm{H}$-benzotriazole (FOQ > 40\%), and the five PFCs (FOQ = 20\%) did not display a significant response in these bioassays, except a weak response $\left(R R_{a / \max }<\right.$ 10\%) for PFOS and PFHxS in ER-MMV-Luc. Hence, they are unlikely to induce any endocrine disrupting activity via these receptors, although they can induce health risks in humans by several other molecular mechanisms e.g. PFCs ${ }^{28,31}$ or metolachlor ${ }^{30}$. Three compounds (MeDPC, desethylatrazine and atrazine) triggered an AhR response in a species- and cell typespecific manner. To our best knowledge, these results are the first recorded for these cell lines. The compounds were frequently detected in raw water samples; hence their activities may be a matter of concern. Meanwhile, chlorpyrifos, BPA, fluoranthene, phenanthrene and $\mathrm{B}[\mathrm{a}] \mathrm{P}$ were active on several receptors. AhR and ER were more general targets for both agonistic and antagonistic activities, responding to respectively eight and six compounds, while GR, PR and AR were targets only for antagonism (see Figure S1 for detailed clusters).

287 Chlorpyrifos caused both agonistic and antagonistic activities towards AhR and ER and only antagonized PR. Therefore, chlorpyrifos appears to be a potential ED. The result was consistent with previous in vitro reports concerning this compound showing activation of

$290 \mathrm{AhR}^{30,32}$ and $\mathrm{ER}^{33-35}$ and with in vivo estrogenic activity observed in mammary gland in female

291 rats $^{36}$. The EU legislation imposes a limit of $0.1 \mu \mathrm{g} / \mathrm{L}$ in drinking water for total pesticides ${ }^{4}$,

292 which is equivalent to $0.3 \mathrm{nM}$ chlorpyrifos, 10000 fold lower than the lowest observed effect

293 concentration of chlorpyrifos at $5 \mu \mathrm{M}$ (Figures 1B, E', H, and J) in our study. However, due to 
294 a high bioconcentration factor (e.g. 100 to 5100 in fish $^{37}$ ), a high documented toxicological 295 activity ${ }^{35,36,38}$ including this study, a considerably high contamination potential due to the 296 current use in the US and a very recent ban in the EU, the monitoring of chlorpyrifos should 297 be specifically indicated in the legislation. In US, potential exposure to chlorpyrifos in drinking water based on model estimates continues to exceed safe levels ${ }^{39}$.

300 BPA is a ubiquitous contaminant, prevalent also in water, including drinking water ${ }^{40-42}$, whose ability to activate ER-mediated pathways is well documented ${ }^{4-45}$ and has been confirmed in this study. However, its activity does not always involve estrogen-mediated mechanisms as shown in human endometrial stromal fiboblasts ${ }^{46}$ or in human endometrial adenocarcinoma cells where it prevented the proteasome-mediated degradation of $\mathrm{ER} \beta^{47}$. In addition, BPA inhibited the activities of all the reference compounds in the T47-D transgenic cell lines: T47D-Luc, TGRM-Luc, TARM-Luc, and PR-TM-Luc, while only anti-androgenic was previously shown in in vitro reporter gene assays ${ }^{26,27,48}$. BPA was present in Wallonia raw water at $\mathrm{C}_{\max }$

$308=31 \mathrm{ng} / \mathrm{L}$ but rarely detected $(\mathrm{FOQ}=9.1 \%)^{17}$. Currently, BPA does not appear to pose a threat

309 to these drinking water sources. However, due to its significant activity, BPA should be listed 310 for monitoring in the Council Directive 98/83/EC 4 .

312 PAHs are a diverse class of toxicants, among which several are well known as genotoxic carcinogens ${ }^{49}$. Also, they activate $A h R^{50-52}$ as one of their major toxicity pathways and interfere with estrogenic signaling through direct or indirect estrogen-like effects ${ }^{53,54}$ and anti-estrogenic effects ${ }^{54,55}$. Besides, it was shown in the $\mathrm{EU}^{56}$ that these compounds can be present in drinking water at concentrations above the maximal limits defined in the Drinking Water Directive ${ }^{4}$.

317 We not only confirmed the finding of weak, but significant induction of the rat AhR response 318 to fluoranthene (but not for phenanthrene) in DR-H4IIE ${ }^{52}$, but also showed that both strongly antagonized TCDD-induction in the human HepG2-Luc and T47-D-Luc. We also newly discovered the strong antagonistic effects of both compounds towards androgens in TARM- 
322 water intended for human consumption ${ }^{4}$. Regarding their significant endocrine disrupting

323 activities, especially anti-AhR and anti-AR towards human-based cell lines and their presence

324 in water sources, we propose to add fluoranthene and phenanthrene to the list of drinking 325 water monitoring in the EU.

$327 \mathrm{~B}[\mathrm{a}] \mathrm{P}$ is known as a potent endocrine and growth disruptor, particularly altering the AhR 328 pathway and displaying both estrogenic and anti-estrogenic activity in several systems ${ }^{30,57,58}$. 329 In this study, B[a]P significantly modified the transcriptional activities of all five receptors in all 330 seven cell lines. It was a strong AhR agonist in DR-H4IIE and caused both agonistic and 331 partially antagonistic activities in HepG2-Luc, as documented previously ${ }^{50,51}$. B[a]P also displayed an agonistic and a partial antagonistic activity in ER-MMV-Luc. It was shown that the estrogenic activity of $\mathrm{B}[\mathrm{a}] \mathrm{P}$ in $\mathrm{MCF}-7$ cells required the activation of the $\mathrm{AhR}$ and the subsequent induction of cytochrome P450 enzymes to produce estrogenic B[a]P metabolites, most notably 3-OH-B[a]P ${ }^{59}$. Indeed, B[a]P failed to stimulate ER-dependent reporter luciferase activity in AhR-knockout MCF-7 cells, indicating that the estrogenic-activity of $\mathrm{B}[\mathrm{a}] \mathrm{P}$ is a "secondary" response driven by its activation of the AhR signaling pathway.

However, the most striking result was the enhanced response observed in T47-D-Luc exposed to $\mathrm{B}[\mathrm{a}] \mathrm{P}$ with a response 10 -fold higher than the maximum response to TCDD. A "pure" AhR antagonist, GNF315 ${ }^{60}$ at $10 \mu \mathrm{M}$ inhibited the B[a]P-induced AhR activation in T47-D-Luc by more than half, from $R_{a / \max }=1061 \%$ to $R_{a} / \max =346 \%$ (Figure S2). However, the other AhR antagonist, $\mathrm{CH}-223191$ did not affect the $\mathrm{B}[\mathrm{a}] \mathrm{P}$ activity. $\mathrm{CH}-223191$ had also failed to inhibit

344 the stimulation of AhR-DNA binding of beta-naphthoflavon (a PAH-like chemical) ${ }^{61}$. 345 Meanwhile, ER antagonists (fadrozole and fulvestrant) at $1 \mu \mathrm{M}$ did not affect the cells' 346 response to $\mathrm{B}[\mathrm{a}] \mathrm{P}$ (data not shown). Thus, the $\mathrm{B}[\mathrm{a}] \mathrm{P}$-induced enhancement of $\mathrm{AhR}$ activation 347 seems to be partially dependent on the AhR activity, but unrelated to the ER activity. This 348 enhancement could be due to some mechanism acting downstream of AhR activation that is 
349 triggered by B[a]P specifically in mammary gland cells. This is consistent with the observed

350 enhancement (2.5-fold) of ER activation in ER-MMV-Luc, also derived from human mammary

351 gland cells (MCF-7). T47-D cells are also used in the reporter cell-assays for progesterone,

352 glucocorticoid and androgen. We also observed an enhanced response (about 2-fold) to 353 progesterone in PR-TM-Luc, consistent with a specific enhancement mechanism in these 354 cells, but antagonism against glucocorticoid and androgen. It is important to mention here that 355 the parent T47-D cells produce their endogenous PR, which is thus also present in the TGRM-

356 Luc and TARM-Luc that contain a transgene coding, respectively for exogenous GR or AR.

357 This explains why the initial antagonism of GR and AR observed in these lines at lower B[a]P 358 concentrations was dominated at higher concentrations by the enhanced PR response. 359 Further investigations will be required to fully understand the actions of $B[a] P$ in these cells. 360 In addition, exposure to $\mathrm{B}(\mathrm{a}) \mathrm{P}$ has been shown to facilitate the migration and invasion of mammary epithelial cells (MCF-7 and MDA-MB-231) due to perturbation of the inflammation mediators and dysregulation of the tumorigenic miRNAs ${ }^{62}$.

364 Such an enhancement is extremely concerning in terms of human exposure to B[a]P which is mostly via food consumption rather than via drinking water. $\mathrm{B}[\mathrm{a}] \mathrm{P}$ exposure resulted in a maximal response (10-fold higher than TCDD) at only $10 \mu \mathrm{M}$, while inductions similar to that of TCDD were already observed at $2.5 \mu \mathrm{M}$ in the human mammary gland T47-D-Luc. Although $\mathrm{B}[\mathrm{a}] \mathrm{P}$ is rapidly metabolized and thereby quickly eliminated from the body ${ }^{63}, \mathrm{~B}[\mathrm{a}] \mathrm{P}$ is still the ubiquitous $\mathrm{PAH}$ contaminant in human samples ${ }^{64}$. B[a]P contamination can be found at 7.1 $\mathrm{nM}$ in the follicular fluid of women who smoke ${ }^{65}$ or $20 \mathrm{nM}$ in serum samples from autopsy cases of African American females ${ }^{64}$. Therefore, a 100 -fold increased exposure up to $2.5 \mu \mathrm{M}$ of $\mathrm{B}[\mathrm{a}] \mathrm{P}$ in blood could be realistic due to the chronic exposure of highly exposed subpopulations or acute exposure due to food contamination incidents. 


\subsection{Activities of the mixtures}

376 The ED mixture consisted of the 18 compounds at their concentrations in a nM range, 377 corresponding to 1000-fold their maximum water level, except for the two pesticides DPC and Me-DPC (Table 1). The ED, PAH and PEST mixtures caused an agonistic effect on AhR in DR-H4IIE and on ER in ER-MMV-Luc. The AhR agonistic effect of the ED and PAH mixtures could be reproduced using only their main contributor, $\mathrm{B}[\mathrm{a}] \mathrm{P}$, while the very weak activity of the PEST mixtures was probably due to the addition of the activities of its components, each individually being too weak to be detected. In contrast, the ER agonistic activity could be attributed to the presence of either BPA (in PEST), B[a]P (in PAH), or both (in ED). Noticeably, the ED mixture already agonized rat AhR at concentration of 100 fold the water levels, (Figure 2A1) at which the mixture contained $14 \mathrm{nM} \mathrm{B}[\mathrm{a}] \mathrm{P}$, a concentration realistically observed in human fluids ${ }^{64,65}$.

None of the mixtures displayed any effect in either HepG2-Luc or T47-D-Luc in reporter gene assays, except for a weak agonistic effect of the ED mixture for both cell lines (Table 2). In contrast, EROD assays revealed a moderate agonistic effect for the PAH mixture in T47-DLuc (Figure 2B1) and a strong antagonistic effect for the ED and PEST mixtures, and to a lesser extent, for the PAH mixture in HepG2-Luc (Figure 2B2). This greater sensitivity of EROD assays for measuring CYP1A activity, at least for the two human AhR cell lines, allowed for a better detection of agonistic, but also antagonistic activities of the mixtures, possibly due to the lower TCDD concentration used in co-exposure experiments. However, contrary to reporter gene assays, antagonism in EROD assays could also result from the inhibition of the CYP1A enzyme activity by the mixtures, which may not be detected in the reporter gene assays. The PEST mixture rather than the PAH mixture induced a similar inhibition on CYP1A activity in HepG2-Luc, indicating its components to be the actual chemicals responsible for this mixture effect. In fact, exposure to pesticides i.e. atrazine and chlorpyrifos showed an antagonistic effect on CYP enzymes in common carp gills ${ }^{66}$, while benzotriazole induced

402 down-regulation of CYP1A1 in the liver, gills and intestines of medakas ${ }^{67}$ and 1- 
aminobenzotriazole, along with other benzotriazole derivatives, is a well-known CYP

404 inhibitor 68,69 .

\section{Conclusions}

407 We tested the endocrine disrupting activities of 18 compounds shown to be present at trace concentrations in raw water intended for drinking water production in Wallonia. Both pure solutions of each compound and mixtures were studied for their ability to agonize and antagonize the transcriptional activities of a panel of five receptors, listed as $A h R, E R, A R, P R$ and GR. Among these compounds, chlorpyrifos, BPA, fluoranthene, phenanthrene, and B[a]P demonstrated significant activities which involved more than one mechanism. Their presence in raw water source should be monitored more strictly. BPA, fluoranthene, and phenanthrene should be added to the list of monitoring due to their potential endocrine disrupting activities.

$415 \mathrm{~B}[\mathrm{a}] \mathrm{P}$ alone or with BPA were the main contributors for the agonistic activities of the ED and

$416 \mathrm{PAH}$ mixtures towards the rat AhR the human ER. EROD assays were able to reveal the 417 antagonistic effect of the mixtures in DR-HepG2 cells, which had not been observed in the 418 reporter gene assays. The results revealed the multi-endocrine disrupting activities of several contaminants in raw water intended for drinking water production, some of them not being mentioned in the EU legislation relating to monitoring of drinking water quality. Their (anta)agonistic effects on different receptors with the potential for additive or inhibitory effects in the mixtures should be considered in their risk assessments.

424 Conflict of interest: The authors declare that there is no conflict of interest.

425 Acknowledgements: This project has received funding from the European Union's Horizon 2020 research and innovation program under the Marie Skłodowska-Curie grant agreement No. 722634. Muller M. is "Maître de Recherche" at the "Fonds National de la Recherche Scientifique". ". We thank the three anonymous reviewers for their insightful comments which helped to improve the manuscript. 
(1) WHO. Drinking water. https://www.who.int/news-room/fact-sheets/detail/drinkingwater.

(2) US EPA. Safe Drinking Water Act (SDWA). https://www.epa.gov/sdwa.

(3) NHMRC (National Health and Medical Research Council). Australian Drinking Water Guidelines; 2011.

(4) EU. Council Directive 98/83/EC of 3 November 1998 on the Quality of Water Intended for Human Consumption; 1998. https://doi.org/10.1017/cbo9780511610851.055.

(5) Gore, A. C.; Chappell, V. A.; Fenton, S. E.; Flaws, J. A.; Nadal, A.; Prins, G. S.;

(6) UNEP/WHO. State of the Science of Endocrine Disrupting Chemicals-2012 United Nations Environment Programme/World Health Organization; Geneva, Switzerland, 2013.

(7) Demeneix, B.; Slama, R. Endocrine Disruptors : From Scientific Evidence to Human Health Protection; 2019.

(8) Balaguer, P.; Delfosse, V.; Bourguet, W. Mechanisms of Endocrine Disruption through Nuclear Receptors and Related Pathways. Curr. Opin. Endocr. Metab. Res. 2019, 7, 1-8. https://doi.org/10.1016/j.coemr.2019.04.008.

(9) Fujisawa-Sehara, A.; Sogawa, K.; Yamane, M.; Fujii-Kuriyama, Y. Characterization of

(10) Klinge, C. M. Part III: Steroid Hormone Receptors and Signal Transduction Processes. In Principles of Endocrinology and Hormone Action; 2016; pp 1-47. https://doi.org/10.1007/978-3-319-27318-1_9-1.

457 (11) Willemsen, P.; Scippo, M. L.; Kausel, G.; Figueroa, J.; Maghuin-Rogister, G.; Martial, 

Activity. Anal. Bioanal. Chem. 2004, 378 (3), 655-663. https://doi.org/10.1007/s00216-003-2217-2.

(12) Jobling, S. Review of Suggested Testing Methods for Endocrine-Disrupting Chemicals. Pure Appl. Chem. 1998, 70 (9), 1805-1827. https://doi.org/https://doi.org/10.1351/pac199870091805.

(13) Grimaldi, M.; Boulahtouf, A.; Delfosse, V.; Thouennon, E.; Bourguet, W.; Balaguer, P. Reporter Cell Lines for the Characterization of the Interactions between Human

(14) Charles, G. D. In Vitro Models in Endocrine Disruptor Screening. ILAR J. 2004, 45 (4), 494-501. https://doi.org/10.1093/ilar.45.4.494.

(15) Legler, J.; Zeinstra, L. M.; Schuitemaker, F.; Lanser, P. H.; Bogerd, J.; Brouwer, A.; Vethaak, A. D.; De Voogt, P.; Murk, A. J.; Van Der Burg, B. Comparison of in Vivo and in Vitro Reporter Gene Assays for Short-Term Screening of Estrogenic Activity. Environ. Sci. Technol. 2002, 36 (20), 4410-4415. https://doi.org/10.1021/es010323a.

(16) Lewin, G.; Escher, S. E.; van der Burg, B.; Simetska, N.; Mangelsdorf, I. Structural Features of Endocrine Active Chemicals - A Comparison of in Vivo and in Vitro Data. Reprod. Toxicol. 2015, 55, 81-94.

https://doi.org/https://doi.org/10.1016/j.reprotox.2014.10.009.

(17) Frippiat, C.; Bémelmans, S.; Burlion, N.; Carbonnelle, P.; Chalon, C.; Delvaux, A.; Galloy, A.; Marneffe, Y.; Nadin, C.; Nix, P.; et al. Recherche de Perturbateurs Endocriniens et d'autres Substances d'intérêt Récent Dans Les Eaux En Vue de La Protection de La Santé Publique et de l'environnement. Programme de Recherche « BIODIEN » - Rapport Final; 2018; Vol. 2018-01690. https://doi.org/10.3917/presa.181.0441.

(18) Amakura, Y.; Tsutsumi, T.; Yoshimura, M.; Nakamura, M.; Handa, H.; Matsuda, R.; Teshima, R.; Watanabe, T. Detection of Aryl Hydrocarbon Receptor Activation by 
Some Chemicals in Food Using a Reporter Gene Assay. Foods 2016, 5 (1), 15. https://doi.org/10.3390/foods5010015.

(19) Doan, T.; Berntsen, H.; Zimmer, K.; Verhaegen, S.; Ropstad, E.; Connolly, L.; Igout, A.; Muller, M.; Scippo, M. A Realistic Mixture of Persistent Organic Pollutants (POPs) Inhibits the Transactivation Activity of the Aryl Hydrocarbon Receptor (AhR) in Vitro. Environ. Pollut. 2019, 254, 113098. https://doi.org/10.1016/j.envpol.2019.113098.

(20) Van der Heiden, E.; Bechoux, N.; Muller, M.; Sergent, T.; Schneider, Y. J.; Larondelle,

(21) Garrison, P. M.; Tullis, K.; Aarts, J. M. M. J. G.; Brouwer, A.; Giesy, J. P.; Denison, M. S. Species-Specific Recombinant Cell Lines as Bioassay Systems for the Detection of 2,3,7,8-Tetrachlorodibenzo- p -Dioxin-like Chemicals. Toxicol. Sci. 1996, 30 (2), 194 203. https://doi.org/10.1093/toxsci/30.2.194.

(22) Hamers, T.; Kamstra, J. H.; Sonneveld, E.; Murk, A. J.; Kester, M. H. A.; Andersson, P. L.; Legler, J.; Brouwer, A. In Vitro Profiling of the Endocrine-Disrupting Potency of Brominated Flame Retardants. Toxicol. Sci. 2006, 92 (1), 157-173. https://doi.org/10.1093/toxsci/kfj187.

(23) Simon, C.; Onghena, M.; Covaci, A.; Van Hoeck, E.; Van Loco, J.; Vandermarken, T.; Van Langenhove, K.; Demaegdt, H.; Mertens, B.; Vandermeiren, K.; et al. Screening of Endocrine Activity of Compounds Migrating from Plastic Baby Bottles Using a MultiReceptor Panel of in Vitro Bioassays. Toxicol. Vitr. 2016, 37, 121-133. https://doi.org/10.1016/j.tiv.2016.09.008.

(24) Schiwy, A.; Brinkmann, M.; Thiem, I.; Guder, G.; Winkens, K.; Eichbaum, K.; Nüßer, L.; Thalmann, B.; Buchinger, S.; Reifferscheid, G.; et al. Determination of the CYP1AInducing Potential of Single Substances, Mixtures and Extracts of Samples in the Micro-EROD Assay with H4IIE Cells. Nat. Protoc. 2015, 10 (11), 1728-1741. 
https://doi.org/10.1038/nprot.2015.108.

(25) OECD. Test No. 455: Performance-Based Test Guideline for Stably Transfected Transactivation In Vitro Assays to Detect Estrogen Receptor Agonists and Antagonists. 2016. https://doi.org/10.1787/20745788.

(26) Kojima, H.; Takeuchi, S.; Sanoh, S.; Okuda, K.; Kitamura, S.; Uramaru, N.; Sugihara, K.; Yoshinari, K. Profiling of Bisphenol A and Eight Its Analogues on Transcriptional Activity via Human Nuclear Receptors. Toxicology 2019, 413 (November 2018), 4855. https://doi.org/10.1016/j.tox.2018.12.001.

(27) Molina-Molina, J. M.; Amaya, E.; Grimaldi, M.; Sáenz, J. M.; Real, M.; Fernández, M. F.; Balaguer, P.; Olea, N. In Vitro Study on the Agonistic and Antagonistic Activities of Bisphenol-S and Other Bisphenol-A Congeners and Derivatives via Nuclear Receptors. Toxicol. Appl. Pharmacol. 2013, 272 (1), 127-136. https://doi.org/10.1016/j.taap.2013.05.015.

(28) Brunner, A. M.; Dingemans, M. M. L.; Baken, K. A.; van Wezel, A. P. Prioritizing Anthropogenic Chemicals in Drinking Water and Sources through Combined Use of Mass Spectrometry and ToxCast Toxicity Data. J. Hazard. Mater. 2019, 364 (April 2018), 332-338. https://doi.org/10.1016/j.jhazmat.2018.10.044.

(29) Leusch, F. D. L.; Khan, S. J.; Gagnon, M. M.; Quayle, P.; Trinh, T.; Coleman, H.; Rawson, C.; Chapman, H. F.; Blair, P.; Nice, H.; et al. Assessment of Wastewater and Recycled Water Quality: A Comparison of Lines of Evidence from Invitro, Invivo and Chemical Analyses. Water Res. 2014, 50, 420-431. https://doi.org/10.1016/j.watres.2013.10.056.

(30) Neale, P. A.; Altenburger, R.; Aït-Aïssa, S.; Brion, F.; Busch, W.; de Aragão Umbuzeiro, G.; Denison, M. S.; Du Pasquier, D.; Hilscherová, K.; Hollert, H.; et al. Development of a Bioanalytical Test Battery for Water Quality Monitoring: Fingerprinting Identified Micropollutants and Their Contribution to Effects in Surface Water. Water Res. 2017, 123, 734-750. https://doi.org/10.1016/j.watres.2017.07.016. (31) Li, K.; Gao, P.; Xiang, P.; Zhang, X.; Cui, X.; Ma, L. Q. Molecular Mechanisms of 
PFOA-Induced Toxicity in Animals and Humans: Implications for Health Risks. Environ. Int. 2017, 99, 43-54. https://doi.org/10.1016/j.envint.2016.11.014.

544

(32) Takeuchi, S.; lida, M.; Yabushita, H.; Matsuda, T.; Kojima, H. In Vitro Screening for Aryl Hydrocarbon Receptor Agonistic Activity in 200 Pesticides Using a Highly Sensitive Reporter Cell Line, DR-EcoScreen Cells, and in Vivo Mouse Liver Cytochrome P450-1A Induction by Propanil, Diuron and Linuron. Chemosphere 2008, 74 (1), 155-165. https://doi.org/https://doi.org/10.1016/j.chemosphere.2008.08.015.

(33) Raun Andersen, H.; Vinggaard, A. M.; Høj Rasmussen, T.; Gjermandsen, I. M.; Cecilie Bonefeld-Jørgensen, E. Effects of Currently Used Pesticides in Assays for Estrogenicity, Androgenicity, and Aromatase Activity in Vitro. Toxicol. Appl. Pharmacol. 2002, 179 (1), 1-12. https://doi.org/https://doi.org/10.1006/taap.2001.9347.

(34) Kojima, H.; Katsura, E.; Takeuchi, S.; Niiyama, K.; Kobayashi, K. Screening for Estrogen and Androgen Receptor Activities in 200 Pesticides by in Vitro Reporter Gene Assays Using Chinese Hamster Ovary Cells. Environ. Health Perspect. 2004, 112 (5), 524-531. https://doi.org/10.1289/ehp.6649.

(35) Juberg, D. R.; Gehen, S. C.; Coady, K. K.; LeBaron, M. J.; Kramer, V. J.; Lu, H.; Marty, M. S. Chlorpyrifos: Weight of Evidence Evaluation of Potential Interaction with the Estrogen, Androgen, or Thyroid Pathways. Regul. Toxicol. Pharmacol. 2013, 66 (3), 249-263. https://doi.org/10.1016/j.yrtph.2013.03.003.

(36) Ventura, C.; Nieto, M. R. R.; Bourguignon, N.; Lux-Lantos, V.; Rodriguez, H.; Cao, G.; Randi, A.; Cocca, C.; Núñez, M. Pesticide Chlorpyrifos Acts as an Endocrine Disruptor in Adult Rats Causing Changes in Mammary Gland and Hormonal Balance. J. Steroid Biochem. Mol. Biol. 2016, 156, 1-9. https://doi.org/10.1016/j.jsbmb.2015.10.010.

(37) Racke, K. D. Environmental Fate of Chlorpyrifos - Reviews of Environmental Contamination and Toxicology; Ware, G. W., Ed.; Springer New York: New York, NY, 1993; pp 1-150. 
(38) Eaton, D. L.; Daroff, R. B.; Autrup, H.; Bridges, J.; Buffler, P.; Costa, L. G.; Coyle, J.; McKhann, G.; Mobley, W. C.; Nadel, L.; et al. Review of the Toxicology of Chlorpyrifos with an Emphasis on Human Exposure and Neurodevelopment. Crit. Rev. Toxicol. 2008, 38 (SUPPL.2), 1-125. https://doi.org/10.1080/10408440802272158.

(39) US EPA. Chlorpyrifos Refined Drinking Water Assessment for Registration Review. 2016, 1-124.

(40) Brueller, W.; Inreiter, N.; Boegl, T.; Rubasch, M.; Saner, S.; Humer, F.; Moche, W.; Schuhmann, A.; Hartl, W.; Brezinka, C.; et al. Occurrence of Chemicals with Known or Suspected Endocrine Disrupting Activity in Drinking Water, Groundwater and Surface Water, Austria 2017/2018. Bodenkultur 2018, 69 (3), 155-173. https://doi.org/10.2478/boku-2018-0014.

(41) Belfroid, A.; Van Velzen, M.; Van der Horst, B.; Vethaak, D. Occurrence of Bisphenol A in Surface Water and Uptake in Fish: Evaluation of Field Measurements. Chemosphere 2002, 49 (1), 97-103. https://doi.org/10.1016/S0045-6535(02)00157-1.

(42) Kuch, H. M.; Ballschmiter, K. Determination of Endocrine-Disrupting Phenolic Compounds and Estrogens in Surface and Drinking Water by HRGC-(NCI)-MS in the Picogram per Liter Range. Environ. Sci. Technol. 2001, 35 (15), 3201-3206. https://doi.org/10.1021/es010034m.

(43) Bonefeld-Jørgensen, E. C.; Long, M.; Hofmeister, M. V.; Vinggaard, A. M. EndocrineDisrupting Potential of Bisphenol A, Bisphenol A Dimethacrylate, 4-n-Nonylphenol, and 4-n-Octylphenol in Vitro: New Data and a Brief Review. Environ. Health Perspect. 2007, 115 (SUPPL1), 69-76. https://doi.org/10.1289/ehp.9368.

(44) Grignard, E.; Lapenna, S.; Bremer, S. Weak Estrogenic Transcriptional Activities of Bisphenol A and Bisphenol S. Toxicol. Vitr. 2012, 26 (5), 727-731. https://doi.org/10.1016/j.tiv.2012.03.013.

(45) Flint, S.; Markle, T.; Thompson, S.; Wallace, E. Bisphenol A Exposure, Effects, and Policy: A Wildlife Perspective. J. Environ. Manage. 2012, 104, 19-34. https://doi.org/10.1016/j.jenvman.2012.03.021. 
(46) Aghajanova, L.; Giudice, L. Effect of Bisphenol A on Human Endometrial Stromal Fibroblasts in Vitro. Reprod Biomed Online 2011, 22 (3). https://doi.org/doi:10.1016/j.rbmo.2010.12.007.

(47) Masuyama, H.; Hiramatsu, Y. Involvement of Suppressor for Gal 1 in the Ubiquitin/Proteasome-Mediated Degradation of Estrogen Receptors. J. Biol. Chem. 2004, 279 (13), 12020-12026. https://doi.org/10.1074/jbc.M312762200.

(48) Sohoni, P.; Sumpter, J. P. Several Environmental Oestrogens Are Also AntiAndrogens. J. Endocrinol. 1998, 158 (3), 327-339. https://doi.org/10.1677/joe.0.1580327.

(49) IARC. IARC Monographs on the Evaluation of Carcinogenic Risks to Humans: Overall Evaluations of Carcinogenicity. IARC Monogr. 1987, 1-42.

(50) Vondráček, J.; Pěnčíková, K.; Neča, J.; Ciganek, M.; Grycová, A.; Dvořák, Z.; Machala, M. Assessment of the Aryl Hydrocarbon Receptor-Mediated Activities of Polycyclic Aromatic Hydrocarbons in a Human Cell-Based Reporter Gene Assay. Environ. Pollut. 2017, 220, 307-316. https://doi.org/10.1016/j.envpol.2016.09.064.

(51) Machala, M.; Vondrá̌, J.; Bláha, L.; Ciganek, M.; Ne`ca, J. Aryl Hydrocarbon Receptor-Mediated Activity of Mutagenic Polycyclic Aromatic Hydrocarbons Determined Using in Vitro Reporter Gene Assay. 2001, 497, 49-62.

(52) Pieterse, B.; Felzel, E.; Winter, R.; Van Der Burg, B.; Brouwer, A. PAH-CALUX, an Optimized Bioassay for AhR-Mediated Hazard Identification of Polycyclic Aromatic Hydrocarbons (PAHs) as Individual Compounds and in Complex Mixtures. Environ. Sci. Technol. 2013, 47 (20), 11651-11659. https://doi.org/10.1021/es403810w.

(53) Gozgit, J. M.; Nestor, K. M.; Fasco, M. J.; Pentecost, B. T.; Arcaro, K. F. Differential Action of Polycyclic Aromatic Hydrocarbons on Endogenous Estrogen-Responsive Genes and on a Transfected Estrogen-Responsive Reporter in MCF-7 Cells. Toxicol. Appl. Pharmacol. 2004, 196 (1), 58-67. https://doi.org/10.1016/j.taap.2003.12.003.

(54) Swedenborg, E.; Rüegg, J.; Hillenweck, A.; Rehnmark, S.; Faulds, M. H.; Zalko, D.; Pongratz, I.; Pettersson, K. 3-Methylcholanthrene Displays Dual Effects on Estrogen 
Receptor (ER) $\alpha$ and ER $\beta$ Signaling in a Cell-Type Specific Fashion. Mol. Pharmacol. 2008, 73 (2), 575-586. https://doi.org/10.1124/mol.107.036384.

(55) Chaloupka, K.; Krishnan, V.; Safe, S. Polynuclear Aromatic Hydrocarbon Carcinogens as Antiestrogens in MCF-7 Human Breast Cancer Cells: Role of the Ah Receptor. Carcinogenesis 1992, 13 (12), 2233-2239. https://doi.org/10.1093/carcin/13.12.2233.

(56) EC. Synthesis Report on the Quality of Drinking Water in the Union Examining Member States' Reports for the 2011-2013 Period, Foreseen under Article 13(5) of Directive 98/83/EC EN. 2016, 13, 1-16.

(57) Ramesh, A.; Harris, K. J.; Archibong, A. E. Reproductive Toxicity of Polycyclic Aromatic Hydrocarbons. In Reproductive and Developmental Toxicology; Elsevier Inc., 2017; pp 745-763. https://doi.org/10.1016/b978-0-12-804239-7.00040-8.

(58) Zhang, Y.; Dong, S.; Wang, H.; Tao, S.; Kiyama, R. Biological Impact of Environmental Polycyclic Aromatic Hydrocarbons (EPAHs) as Endocrine Disruptors. Environ. Pollut. 2016, 213, 809-824. https://doi.org/10.1016/j.envpol.2016.03.050.

(59) Hýžd’alová, M.; Pivnicka, J.; Zapletal, O.; Vázquez-Gómez, G.; Matthews, J.; Neca, J.; Pencíková, K.; Machala, M.; Vondrácek, J. Aryl Hydrocarbon Receptor-Dependent Metabolism Plays a Significant Role in Estrogen-Like Effects of Polycyclic Aromatic Hydrocarbons on Cell Proliferation. Toxicol. Sci. 2018, 165 (2), 447-461. https://doi.org/10.1093/toxsci/kfy153.

(60) Smith, K. J.; Murray, I. A.; Tanos, R.; Tellew, J.; Boitano, A. E.; Bisson, W. H.; Kolluri, S. K.; Cooke, M. P.; Perdew, G. H. Identification of a High-Affinity Ligand That Exhibits Complete Aryl Hydrocarbon Receptor Antagonism. J. Pharmacol. Exp. Ther. 2011, 338 (1), 318-327. https://doi.org/10.1124/jpet.110.178392.

(61) Zhao, B.; DeGroot, D. E.; Hayashi, A.; He, G.; Denison, M. S. Ch223191 Is a LigandSelective Antagonist of the Ah (Dioxin) Receptor. Toxicol. Sci. 2010, 117 (2), 393403. https://doi.org/10.1093/toxsci/kfq217.

(62) Malik, D. e. shahwa.; David, R. M.; Gooderham, N. J. Mechanistic Evidence That Benzo[a]Pyrene Promotes an Inflammatory Microenvironment That Drives the 

3239. https://doi.org/10.1007/s00204-018-2291-z.

656

(63) Denison, M. S.; Soshilov, A. A.; He, G.; Degroot, D. E.; Zhao, B. Exactly the Same but Different: Promiscuity and Diversity in the Molecular Mechanisms of Action of the Aryl Hydrocarbon (Dioxin) Receptor. Toxicol. Sci. 2011, 124 (1), 1-22. https://doi.org/10.1093/toxsci/kfr218.

(64) Ramesh, A.; Kumar, A.; Aramandla, M. P.; Nyanda, A. M. Polycyclic Aromatic Hydrocarbon Residues in Serum Samples of Autopsied Individuals from Tennessee. Int. J. Environ. Res. Public Health 2015, 12 (1), 322-334. https://doi.org/10.3390/ijerph120100322.

(65) Vu, A. T.; Taylor, K. M.; Holman, M. R.; Ding, Y. S.; Hearn, B.; Watson, C. H. Polycyclic Aromatic Hydrocarbons in the Mainstream Smoke of Popular U.S. Cigarettes. Chem Res Toxicol 2015, 28 (8), 1616-1626. https://doi.org/doi:10.1021/acs.chemrestox.5b00190. Polycyclic.

(66) Fu, Y.; Li, M.; Liu, C.; Qu, J. P.; Zhu, W. J.; Xing, H. J.; Xu, S. W.; Li, S. Effect of Atrazine and Chlorpyrifos Exposure on Cytochrome P450 Contents and Enzyme Activities in Common Carp Gills. Ecotoxicol. Environ. Saf. 2013, 94, 28-36. https://doi.org/10.1016/j.ecoenv.2013.04.018.

(67) Tangtian, H.; Bo, L.; Wenhua, L.; Shin, P. K. S.; Wu, R. S. S. Estrogenic Potential of Benzotriazole on Marine Medaka (Oryzias Melastigma). Ecotoxicol. Environ. Saf. 2012, 80, 327-332. https://doi.org/10.1016/j.ecoenv.2012.03.020.

(68) Montellano, P. R. O. de. 1-Aminobenzotriazole: A Mechanism-Based Cytochrome P450 Inhibitor and Probe of Cytochrome P450 Biology. Med Chem (Los Angeles) 2018, 8 (3). https://doi.org/doi:10.4172/2161-0444.1000495.

(69) Correia, M. A.; Ortiz De Montellano, P. R. Inhibition of Cytochrome P450 Enzymes. Cytochrome P450 Struct. Mech. Biochem. Third Ed. 2005, 247-322. https://doi.org/10.1007/0-387-27447-2_7. 
(A) Agonistic (DR-H4IIE)

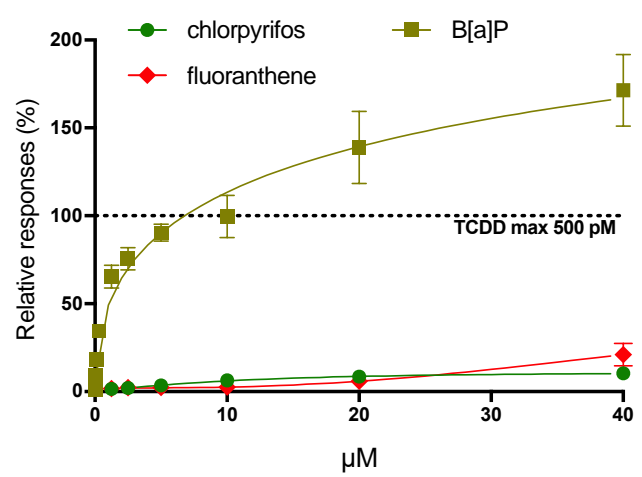

(C) Agonistic (HepG2-Luc)

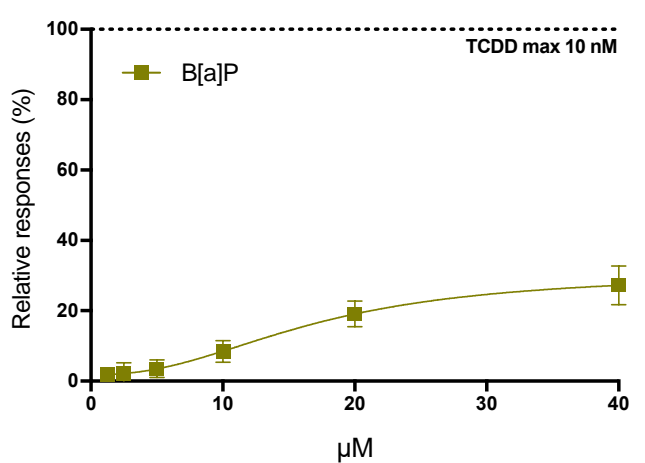

(E) Agonistic T47-D-Luc

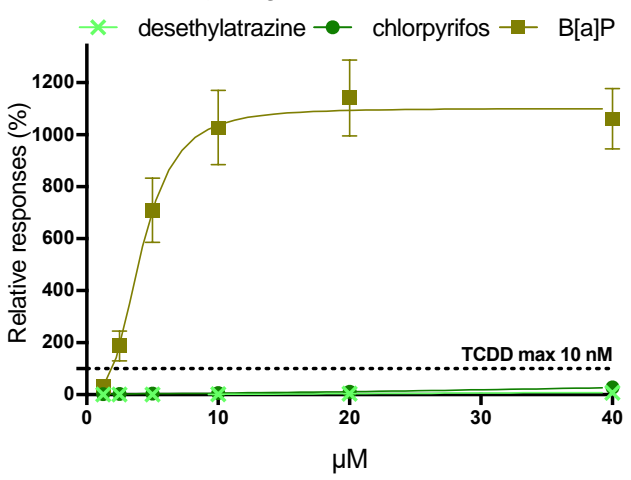

(E') Agonistic T47-D-Luc

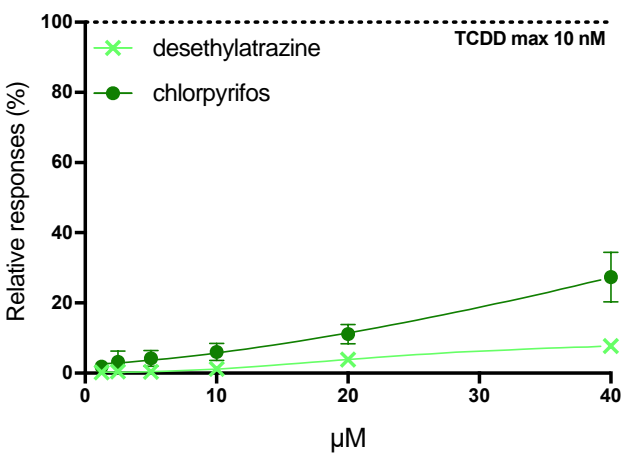

(B) Co-exposure + 15 pM TCDD (DR-H4IIE)

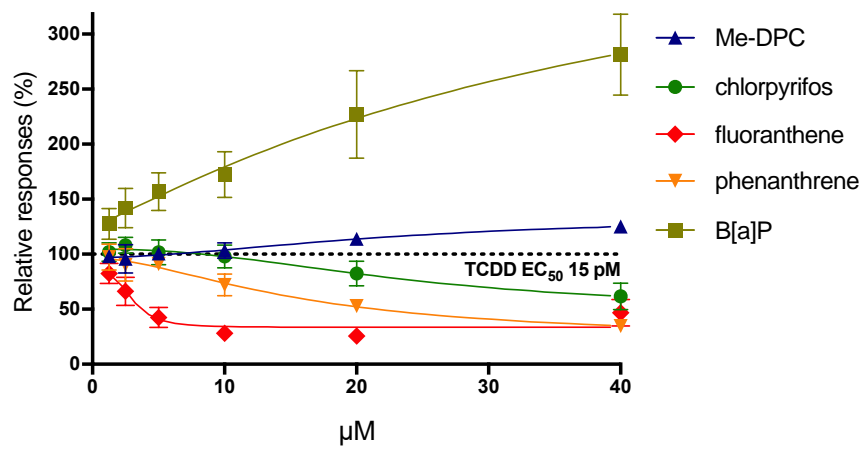

(D) Co-exposure + 650 pM TCDD (HepG2-Luc)

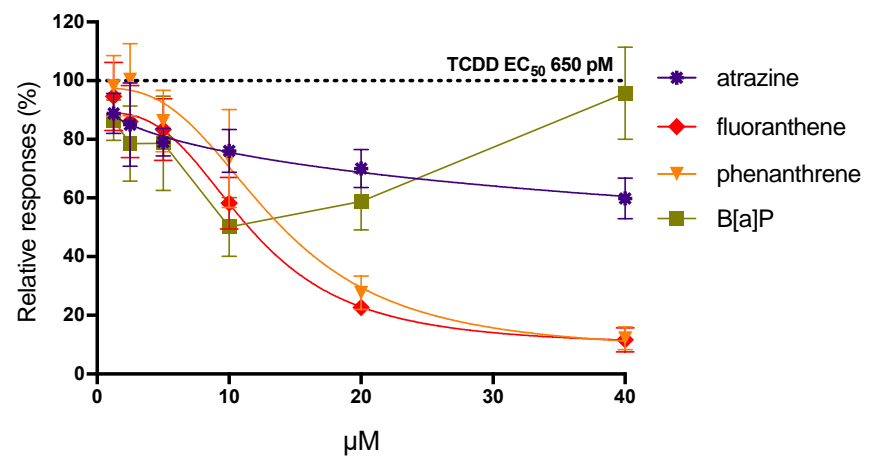

(F) Co-exposure + 150 pM TCDD (T47-D-Luc)

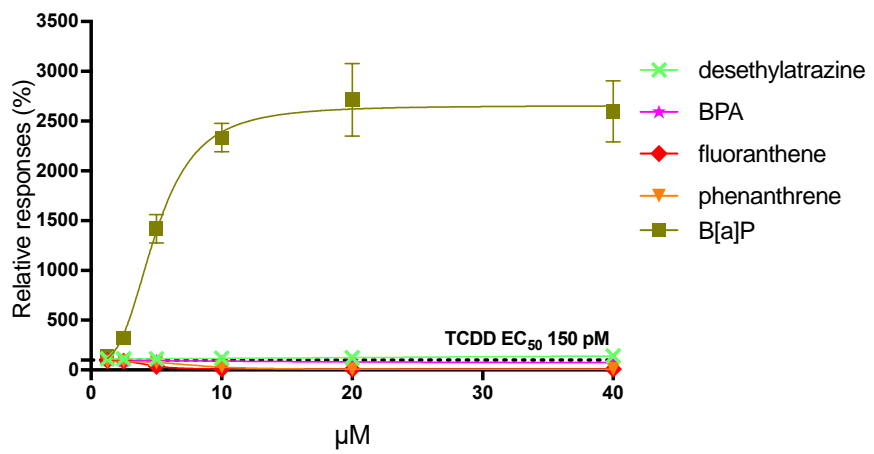

(F') Co-exposure + 150 pM TCDD (T47-D-Luc)

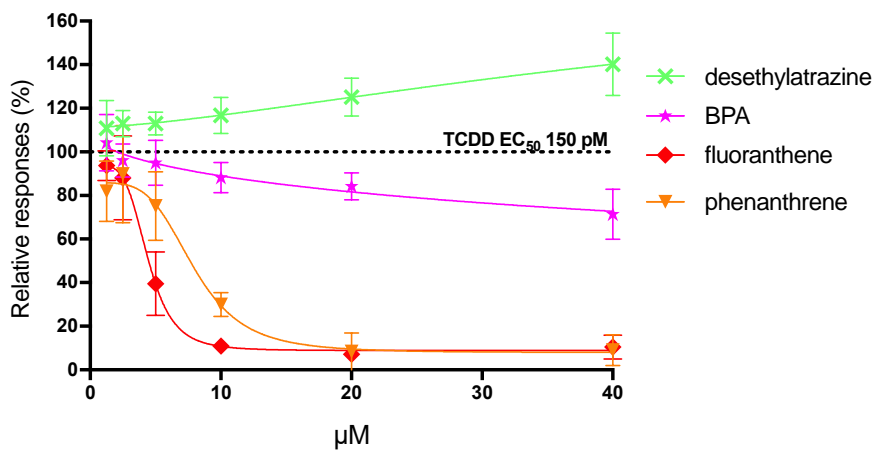


(G) Agonistic (ER-MMV-Luc)

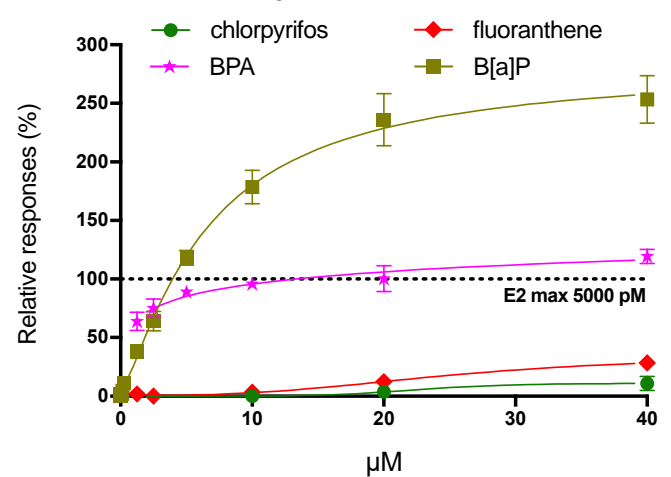

(I) Co-exposure + 10 nM Dex (TGRM-Luc)

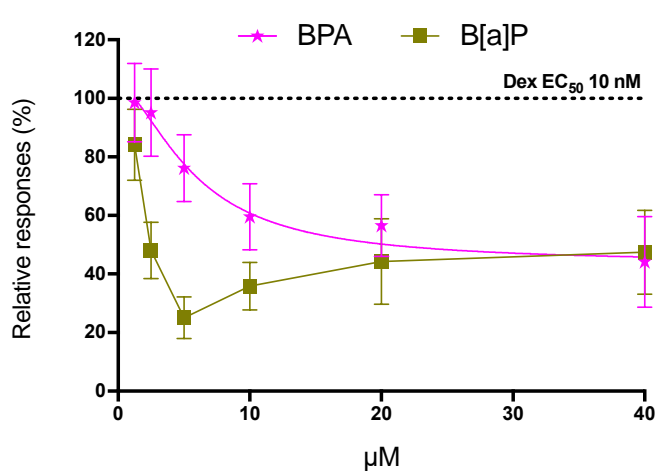

(K) Co-exposure + 400 pM DHT (TARM-Luc)
(H) Co-exposure + 12.5 pM E2 (ER-MMV-Luc)

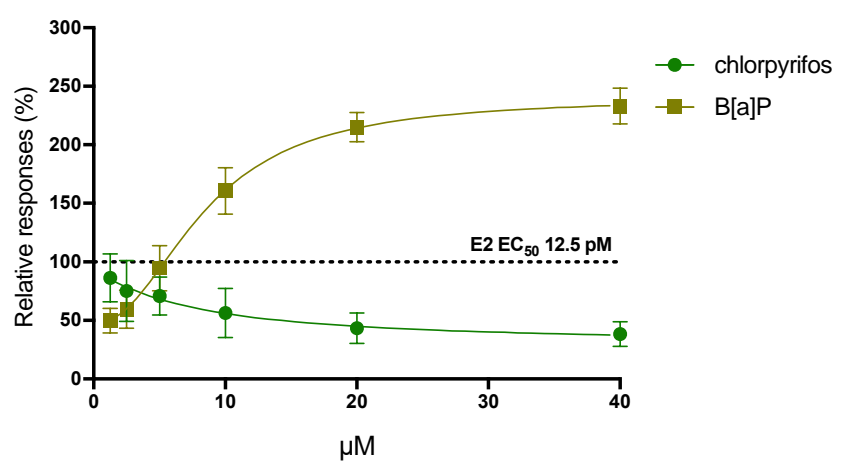

(J) Co-exposure + 1 M P4 (PR-TM-Luc)

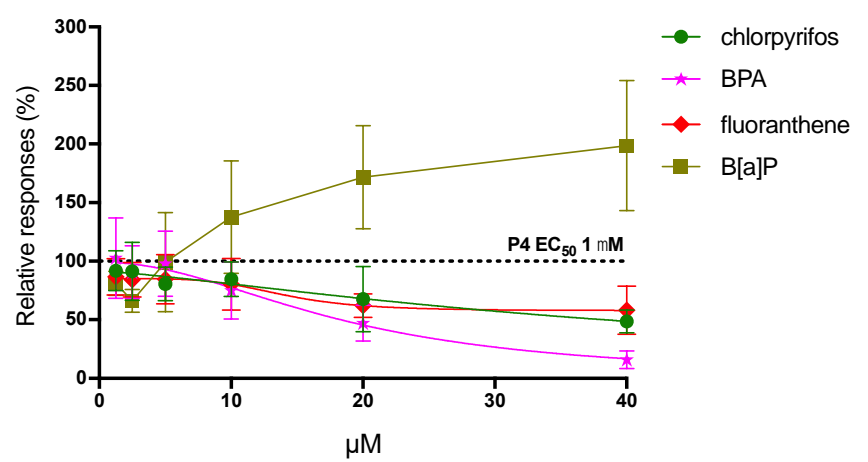

687

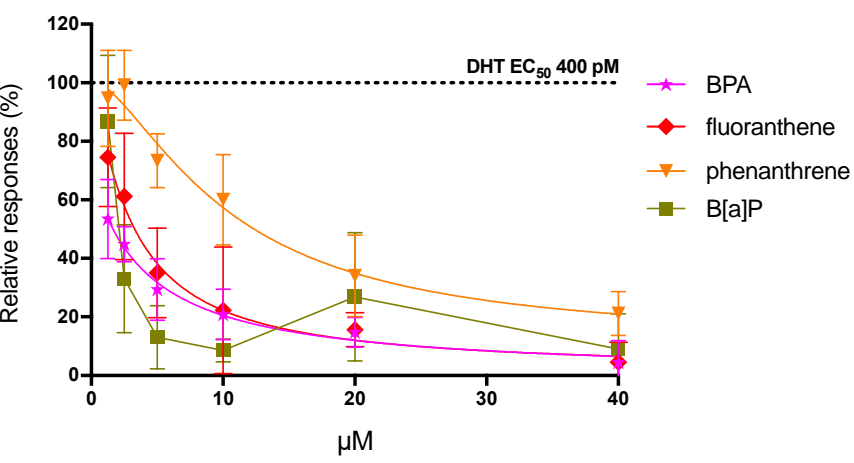

688

689 Figure 1. Dose-response curves of the active chemicals in (A-B) DR-H4IIE, (C-D) HepG2-Luc,

690 (E-F') T47-D-Luc, (G-H) ER-MMV-Luc, (I) TGRM-Luc, (J) PR-TM-Luc, and (K) TARM-Luc,

691 inducible respectively by aryl hydrocarbon, estrogen, glucocorticoid, progesterone, and

692 androgen receptors. (Mean $\pm \mathrm{SD}, \mathrm{n}=3,0.2 \%$ or $0.3 \%$ DMSO for agonistic or co-exposure

693 tests, respectively). Dash lines (100\%) are the maximum response or the response of the

694 corresponding reference compound in agonistic or co-exposure tests, respectively. 
(A1) Agonistic (DR-H4IIE)

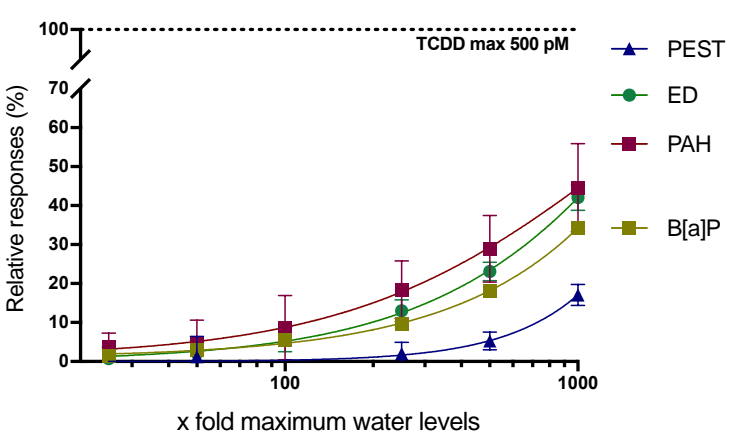

(B1) EROD agonistic (T47-D-Luc)

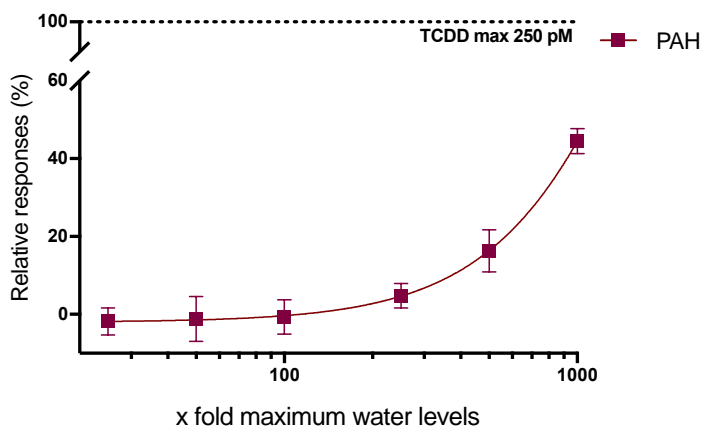

(A2) Agonistic (ER-MMV-Luc)

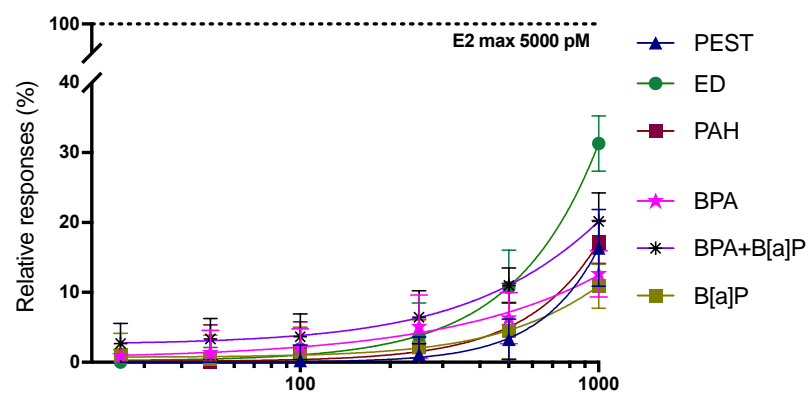

$x$ fold maximum water levels

(B2) EROD co-exposure + 100 pM TCDD (HepG2-Luc)

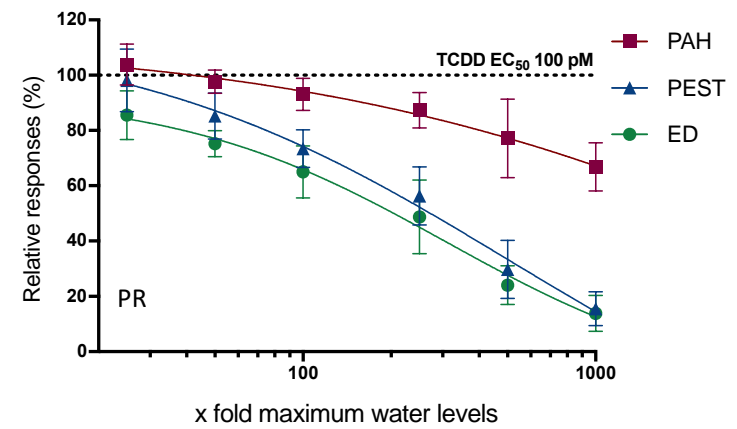

696

Figure 2. (A) Dose-response curves of the mixtures and BPA, B[a]P and BPA+B[a]P in the

698 DR-H4IIE (A1) and ER-MMV-Luc (A2). (B) Dose-response curves of the mixtures in T47-D-

699 Luc (B1) and HepG2-Luc (B2) in EROD assays. (Mean $\pm \mathrm{SD}, \mathrm{n}=3,0.2 \%$ or $0.3 \%$ DMSO for

700 agonistic or co-exposure tests, respectively). Dash lines (100\%) are the maximum response

701 or the response of the corresponding reference compound in agonistic or co-exposure tests,

702 respectively. 
Table 1. List of the 19 compounds most frequently found in raw water samples in the Wallonia and Brussels areas ${ }^{17}$.

\begin{tabular}{|l|l|l|c|c|c|c|}
\hline Compound & CAS & Supplier reference & FOQ $(\%)$ & $C_{\max }(\mathrm{ng} / \mathrm{L})$ & $\mathrm{C}_{\mathrm{m}}(\mathrm{ng} / \mathrm{L})$ & $\mathrm{C}_{\mathrm{t}}(\mu \mathrm{M})$ \\
\hline Desphenyl-chloridazon (DPC) & $6339-19-1$ & AKOS-006278170 & 82 & 21500 & $1230^{*}$ & $8.5^{*}$ \\
\hline Methyl-desphenyl-chloridazon (Me-DPC) & $17254-80-7$ & DRE-C11322500 & 69.7 & 1930 & 1320 & 8.3 \\
\hline Desethylatrazine & $6190-65-4$ & Sigma 36629 & 67.4 & 122 & 111 & 0.59 \\
\hline VIS 01/Chlorothalonil SA & $1418095-02-9$ & Not included & 55.1 & 772 & $\mathrm{ND}$ & $\mathrm{NA}$ \\
\hline Metolachlor ESA & $171118-09-5$ & DRE-CA15171100 & 53.9 & 890 & 450 & 0.47 \\
\hline Atrazine & $1912-24-9$ & Sigma 45330 & 44.2 & 101 & 101 & 1.3 \\
\hline Metazachlor ESA (BH479-8) & $172960-62-2$ & DRE-CA14950020 & 40.4 & 186 & 130 & 0.4 \\
\hline 1H-benzotriazole & $95-14-7$ & Sigma 76457 & 34.7 & 186 & $\mathrm{ND}$ & 1.6 \\
\hline Perfluorooctanesulfonic acid (PFOS) & $1763-23-1$ & Sigma 33829 & 29 & 19.95 & $\mathrm{ND}$ & 0.04 \\
\hline Perfluorooctanoic acid (PFOA) & $335-67-1$ & Sigma 33824 & 28 & 5.51 & $\mathrm{ND}$ & 0.01 \\
\hline Perfluorohexanoic acid (PFHxA) & $307-24-4$ & DRE-C15986910 & 23 & 11.53 & $\mathrm{ND}$ & 0.04 \\
\hline Perfluoroheptanoic acid (PFHpA) & $375-85-9$ & Sigma 342041 & 18 & 2.18 & $\mathrm{ND}$ & 0.01 \\
\hline Perfluorohexanesulfonic acid (PFHxS) & $355-46-4$ & Sigma 50929 & 13 & 15.02 & $\mathrm{ND}$ & 0.03 \\
\hline Simazine & $122-34-9$ & Sigma 32059 & 10.5 & 23 & 28 & 0.14 \\
\hline Chlorpyrifos & $2921-88-2$ & Sigma 45395 & 10.5 & 104 & 92 & 0.26 \\
\hline Bisphenol A (BPA) & $80-05-7$ & Sigma 239658 & 9.1 & 31 & $\mathrm{ND}$ & 0.14 \\
\hline Fluoranthene & $206-44-0$ & Sigma 45504 & 8.4 & 62 & 11 & 0.05 \\
\hline Phenanthrene & $85-01-8$ & Sigma 695114 & 8.4 & 19 & 29 & 0.16 \\
\hline Benzo[a]pyrene (B[a]P) & $50-32-8$ & Sigma B1760 & 8.4 & 70 & 29 & 0.12 \\
\hline
\end{tabular}

FOQ: frequency of quantification (\% of samples), $\mathrm{C}_{\max }$ : maximum concentration quantified in raw water samples. $\mathrm{C}_{\mathrm{m}}$ : measured concentration by LC-MS/MS and GC-MS/MS in the ED mixture. $\mathrm{C}_{\mathrm{t}}$ : the maximum tested concentration in the ED mixture corresponding to 1000 fold maximum water levels, except 100 fold for DPC $\left(^{*}\right)$. ND: not determined. 
Table 2. $\mathrm{EC}_{50}$ and $\mathrm{RR}_{\mathrm{a} / \mathrm{max}}$ values of the agonistic responses to the selected 18 chemicals and four mixtures $(n=3,0.2 \% \mathrm{DMSO})$.

\begin{tabular}{|c|c|c|c|c|c|c|c|c|}
\hline \multirow{2}{*}{ Compound/mixture } & \multicolumn{2}{|c|}{ DR-H4IIE } & \multicolumn{2}{|c|}{ HepG2-Luc } & \multicolumn{2}{|c|}{ T47-D-Luc } & \multicolumn{2}{|c|}{ ER-MMV-Luc } \\
\hline & $\mathrm{EC}_{50} \pm \mathrm{SE}$ & $\mathrm{RR}_{\mathrm{a} / \max }$ & $\mathrm{EC}_{50} \pm \mathrm{SE}$ & $\mathrm{RR}_{\mathrm{a} / \max }$ & $\mathrm{EC}_{50} \pm \mathrm{SE}$ & $\mathrm{RR}_{\mathrm{a} / \mathrm{max}}$ & $\mathrm{EC}_{50} \pm \mathrm{SE}$ & $\mathrm{RR}_{\mathrm{a} / \max }$ \\
\hline DPC & - & - & - & - & - & - & - & - \\
\hline Me-DPC & - & - & - & - & - & - & - & - \\
\hline Desethylatrazine & - & - & - & & $24.1 \pm 4.8$ & 8 & - & - \\
\hline Metolachlor ESA & - & - & - & - & - & - & - & - \\
\hline Atrazine & - & - & - & - & - & - & - & - \\
\hline BH479-8 & - & - & - & - & - & - & - & - \\
\hline 1H-benzotriazole & - & - & - & - & - & - & - & - \\
\hline PFOS & - & - & - & - & - & - & ND & 7 \\
\hline PFOA & - & - & - & - & - & - & - & - \\
\hline PFHXA & - & - & - & - & - & - & - & - \\
\hline PFHpA & - & - & - & - & - & - & - & - \\
\hline PFHxS & - & - & - & - & - & - & ND & 6 \\
\hline Simazine & - & - & - & - & - & - & - & - \\
\hline Chlorpyrifos & $10.5 \pm 2.3$ & 10 & - & - & ND & 27 & $22.6 \pm 17.7$ & 11 \\
\hline BPA & & & - & - & - & - & $1.2 \pm 0.1$ & 119 \\
\hline Fluoranthene & ND & 21 & - & - & - & - & $25.4 \pm 6.4$ & 28 \\
\hline Phenanthrene & - & - & - & - & - & - & - & - \\
\hline $\mathrm{B}[\mathrm{a}] \mathrm{P}$ & ND & 171 & $16.8 \pm 2.3$ & 27 & $4.2 \pm 0.2$ & $1061^{*}$ & $6.5 \pm 0.4$ & $253^{*}$ \\
\hline PFAA & - & - & - & - & - & - & - & - \\
\hline PAH & ND & 45 & - & - & - & 7 & ND & 17 \\
\hline PEST & ND & 17 & - & - & - & - & ND & 16 \\
\hline ED & ND & 42 & ND & 6 & ND & 11 & ND & 32 \\
\hline
\end{tabular}

$\mathrm{EC}_{50}(\mu \mathrm{M}$ for individual compounds and fold water level for mixtures): the concentration inducing half of the maximum activation response; SE: Standard Error; RR $\mathrm{R}_{a / \max }(\%)$ : observed activation efficacy; ND: Not Determined. -: no response at concentration $\leq 40 \mu \mathrm{M}$. *Maximum efficacy observed within the tested concentrations. 
Table 3. $I_{50}$ and $\mathrm{RR}_{\mathrm{i} / \max }$ values of the co-exposure responses to the selected 18 chemicals and four mixtures $(n=3,0.3 \%$ DMSO).

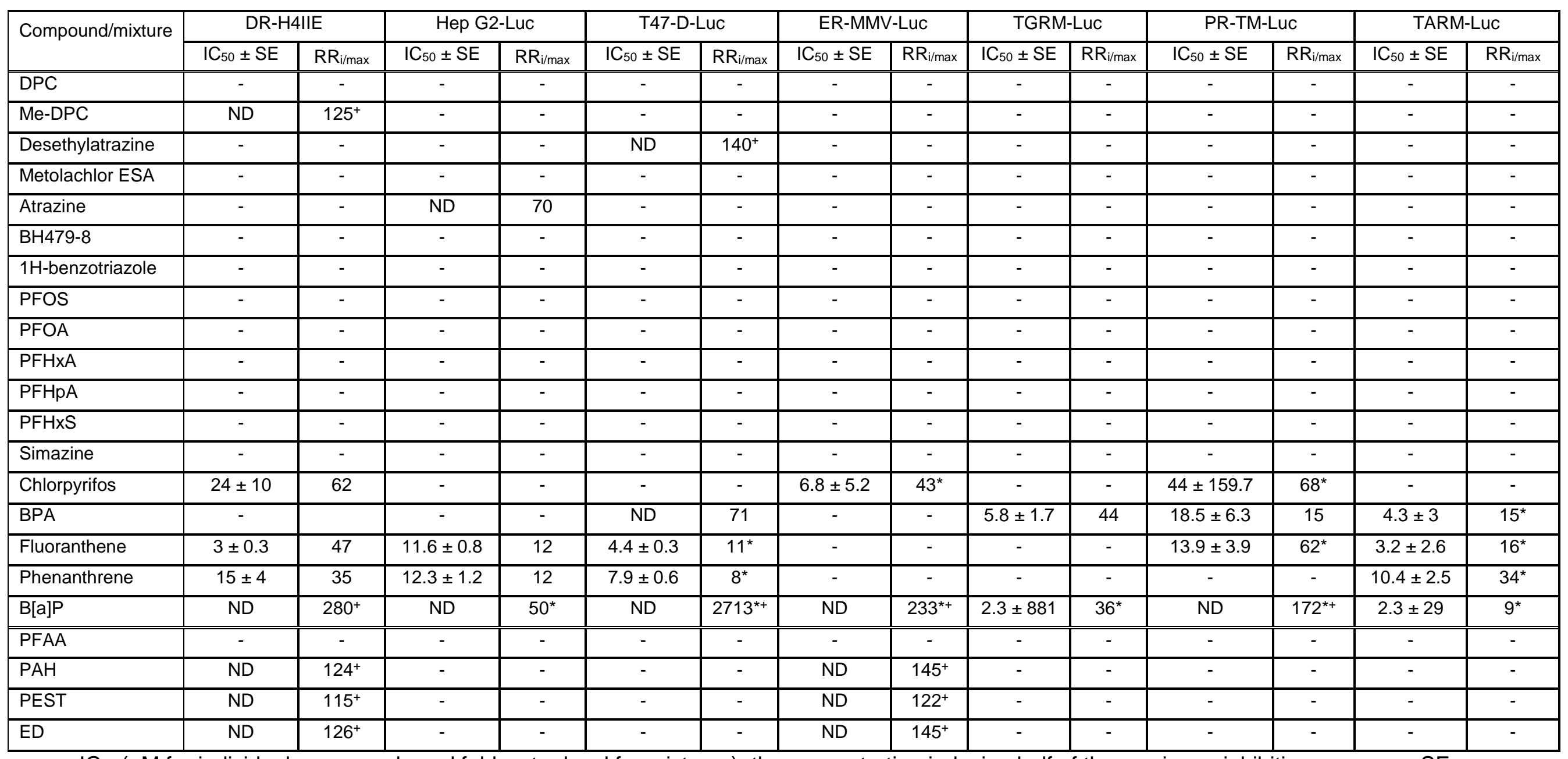

$\mathrm{IC}_{50}(\mu \mathrm{M}$ for individual compounds and fold water level for mixtures): the concentration inducing half of the maximum inhibition response; SE:

Standard Error; $\mathrm{RR}_{\mathrm{i} / \max }(\%)$ : observed inhibition efficacy; ND: Not Determined. -: no response at concentration $\leq 40 \mu \mathrm{M}$. *Maximum efficacy

observed within the tested concentrations. ${ }^{+}$: additive activity. 